\title{
Effect of Harvest Interval on Yields of Four Sudan Grass Sorghum Crosses with Irrigation on the South Coast of Puerto Rico ${ }^{1,2}$
}

\author{
Rubén Caro-Costas ${ }^{3}$
}

\begin{abstract}
Yields of the Sudan grass-sorghum hybrids Space Maker, Grazer A, Sordan 70 , and Graze and Bale averaged $23,028,39,815$ and $54,810 \mathrm{~kg}$ of dry forage/ha/yr when harvested every 30,45 and 60 days, respectively, over a one year period with irrigation. Crude protein percentage of the forage averaged $9.0,6.2$ and $5.0 \%$ for the 30,45 and 60 days cutting intervals, respectively. Sordan 70 and Grazer A were the highest yielders with 30- or 60-day harvest intervals. Sordan 70 outyielded all the other forages at the 45day harvest interval. All the forages had similar crude protein contents at the various cutting intervals except Sordan 70 that had a lower protein content than the other forages at the 30 - and 60-day cutting intervals. All the forages produced similar yields of crude protein at the various cutting intervals except that Sordan 70 which produced more total protein than the other grasses at the 45-day harvest interval.

The very high yields produced by these forages show that the semiarid irrigated region of Puerto Rico can be used to grow forage to supplement pastures in nearby grazing lands during the annual dry season.
\end{abstract}

\section{INTRODUCTION}

In Puerto Rico, cattle production should be concentrated on sloping deep soils in the humid mountain region, where rainfall is generally abundant and well-managed pastures produce high yields of milk and beef as shown by the research summarized by Vicente-Chandler et al. ${ }^{4}$ There are about 200,000 ha of such lands which have few alternative use since they are erodible and little mechanization is possible. Pastures can protect these soils against erosion and little mechanization is required since the cattle graze the forage, and fertilizer can be applied with broad based tractors or by air.

Additional forage is often needed in this region during periods of drought or during the winter, when grasses grow more slowly. This forage can be produced on lands suitable for mechanized production especially

${ }^{1}$ Manuscript submitted to Editorial Board December 26, 1979.

${ }^{2}$ This paper covers work carried out cooperatively between Agricultural Research, Science and Education Administration, USDA and the Agricultural Experiment Station, Mayagüez Campus, University of Puerto Rico, Río Piedras, P.R.

${ }^{3}$ Associate Agronomist in cooperation between the Puerto Rico Agricultural Experiment Station and the Agricultural Research, Science and Education Administration, USDA, Río Piedras, P.R.

${ }^{4}$ Vicente-Chandler, J., Abruña, F., Caro-Costas, R., Figarella, J., Silva, S., and Pearson, R. W. 1974. Intensive Grassland Management in the Humid Tropics, J. Agri. Univ. P.R., Bull. 233. 
where grasses are required in rotation with crops for pest control or planted during the off-season for more profitable crops.

Among the areas suited to mechanized forage production are the heavier irrigated soils near Santa Isabel on the south coast. Little, Vicente-Chandler and Abruña ${ }^{5}$ determined the productivity of well-fertilized irrigated Napier grass in this region. When harvested every 60 days, this grass responded strongly in yield to applications of $\mathrm{N}$ up to 970 $\mathrm{kg} / \mathrm{ha} / \mathrm{yr}$ divided into 6 equal applications. With such management Napier grass produced about $58,000 \mathrm{~kg}$ of dry forage/ha/yr with a crude protein content of $9.4 \%$. However, Caro et al. ${ }^{6}$ in studies at this same location, found that Napier grass cut and chopped as the only source of feed for steers resulted in weight gains of only $0.25 \mathrm{~kg} /$ day $/$ head compared with $0.5 \mathrm{kgs}$ of gain in weight/day when the steers were grazed on adjacent Napier grass pastures. The lower beef yields produced by cattle consuming cut, and chopped Napier grass were explained by the high moisture, silica, and lignin content, and by the low digestibility of the Napier grass stems which they ingested, whereas grazing cattle consumed only the leaves.

Only a few months are required to establish a good stand of Napier grass, which thereafter remains productive indefinitely if properly managed. However, Napier grass is very difficult to eradicate if crops are to be planted on the land later, and for this reason it is not adapted to rotation with crops.

There is, therefore, a need for high yielding forages adapted to mechanized production for cattle feed. They should be easily and quickly established, high yielding (since land and water are expensive) and either easily eradicated or of a limited life span so that they can fit into crop rotation.

The present study compared the effects of various cutting intervals on the yield of four sorghum-sudan grass hybrids with intensive management and irrigation on the semi-arid south coast of Puerto Rico over a 1-year period.

\section{MATERIALS AND METHODS}

The experiment was carried out near Santa Isabel at an elevation of about $20 \mathrm{~m}$. Mean annual temperature is about $26^{\circ} \mathrm{C}$ with average

${ }^{5}$ Little, S., Vicente-Chandler, J., and Abruña, F. 1959. Yield and Protein Content of Irrigated Napiergrass, Guineagrass and Pangolagrass as Affected by Nitrogen Fertilization, Agron. J. 51: 111-13.

${ }^{6}$ Caro-Costas, R., Vicente-Chandler, J., and Burleigh, C. 1961. Beef Production and Carrying Capacity of Heavily Fertilized Irrigated Guinea, Napier and Pangola Grass Pastures on the Semiarid South Coast of Puerto Rico, J. Agri. Univ. P.R., 45 (1): 32-36. 
monthly variations of about $5^{\circ} \mathrm{C}$. Annual rainfall is about $1,000 \mathrm{~mm}$ usually with heavy rains from August to November and dry weather during the remainder of the year.

The soil is Fraternidad clay (Udic Chromusterts, very fine, montmorillonitic isohyperthermic). The surface soil is friable, but the subsoil is rather heavy. The surface soil has $2.8 \%$ organic matter, a $\mathrm{pH}$ of 7.5 , and a cation exchange capacity of $38.68 \mathrm{meq} / 100 \mathrm{~g}$ of soil.

The following sorghum-sudan grass crosses were planted in rows $1 \mathrm{~m}$ apart: Space Maker, Grazer A, Sordan 70, and Graze and Bale. Cutting intervals were 30, 45 and 60 days. All treatments were replicated 4 times in a split-plot design with cutting intervals as the main plots and grasses as the subplots. Sub-plots were $4 \times 4 \mathrm{~m}$.

During dry weather, three inches of water was applied every 10 days by basin irrigation. All plots received 5 metric tons of 15-5-10 fertilizer/ ha/yr applied 6,8 or 12 times depending on the cutting interval. The experiment was planted in December 2, 1975, mowed on January 2, 1976 and thereafter harvested at the prescribed intervals.

The forage produced by each plot was cut and weighed. A subsample was taken in plastic bags to the laboratory for moisture and crude protein $(\mathrm{N} \times 6.25)$ determinations. From these data dry matter yields and protein content of the forage were determined. The experiment was run for one year, at the end of which, the stand of the forages started to decline and the experiment was discontinued.

\section{RESULTS AND DISCUSSIONS}

Table 1 shows that yields of all forages increased with each increase in cutting interval, averaging $23,038,39,815$ and $54,810 \mathrm{~kg}$ of dry forage/ha/ yr when harvested every 30,45 and 60 days, respectively.

Crude protein content of the forage decreased with each increase in cutting interval, averaging $8.9,6.2$ and $5.0 \%$ for the 30 -, 45- and 60-day cutting intervals, respectively.

Average crude protein yields increased with each increase in cutting interval, averaging $2,050,2,468$ and $2,702 \mathrm{~kg}$ of crude protein/ha/ $\mathrm{yr}$ for the 30-, 45- and 60-day cutting intervals, respectively. These data indicate that nitrogen conversion into protein, either from the soil or the applied fertilizer, was more efficient with longer harvest intervals.

With a 30-day cutting interval Grazer A, Sordan 70, and Graze and Bale varieties produced similar and significantly higher dry matter yields than Space Maker. The Space Maker, Grazer A, and Graze and Bale forages had a significantly higher protein content than did Sordan 70 . However, there was no significant difference in protein yields.

With a 45-day harvest interval, Sordan 70 outyielded all the other forages averaging $48,520 \mathrm{~kg}$ of dry forage/ha/yr. There was no significant 
TABLE 1.-Effect of cutting interval on yields and protein content of four well fertilized, irrigated sudansorghum crosses on the semi-arid south coast of Puerto Rico

\begin{tabular}{|c|c|c|c|c|c|c|c|c|c|}
\hline \multirow{2}{*}{$\begin{array}{l}\text { Sudan-sorghum } \\
\text { cross }\end{array}$} & \multicolumn{3}{|c|}{ Cut every 30 days } & \multicolumn{3}{|c|}{ Cut every 45 days } & \multicolumn{3}{|c|}{ Cut every 60 days } \\
\hline & Dry matter & Protein & Crude protein & Dry matter & Protein & Crude protein & Dry matter & Protein & Crude protein \\
\hline & $\mathrm{Kg} / \mathrm{ha} / \mathrm{yr}$ & $\%$ & $K g / h a / y r$ & $\mathrm{Kg} / \mathrm{ha} / \mathrm{yr}$ & $\%$ & $\mathrm{Kg} / \mathrm{ha} / \mathrm{yr}$ & $\mathrm{Kg} / \mathrm{ha} / \mathrm{yr}$ & $\%$ & $K g / h a / y r$ \\
\hline Space Maker & $20,610 b^{1}$ & $9.2 \mathrm{a}$ & $1,900 \mathrm{a}$ & $35,780 \mathrm{~b}$ & $6.6 \mathrm{a}$ & $2,350 \mathrm{~b}$ & $53,730 \mathrm{~b}, \mathrm{c}$ & $5.1 \mathrm{a}$ & $2,760 \mathrm{a}$ \\
\hline Grazer A & $24,850 \mathrm{a}$ & $9.1 \mathrm{a}$ & $2,250 \mathrm{a}$ & $39,090 \mathrm{~b}$ & $6.0 \mathrm{a}$ & $2,340 \mathrm{~b}$ & $56,170 \mathrm{a}, \mathrm{b}$ & $5.1 \mathrm{a}$ & $2,840 \mathrm{a}$ \\
\hline Sordan 70 & 24,030 a & $8.2 \mathrm{~b}$ & $1,970 \mathrm{a}$ & $48,520 \mathrm{a}$ & $6.1 \mathrm{a}$ & $2,980 \mathrm{a}$ & $57,720 \mathrm{a}$ & $4.6 \mathrm{a}$ & $2,650 \mathrm{a}$ \\
\hline Graze and Bale & $22,660 \mathrm{a}$ & $9.2 \mathrm{a}$ & $2,080 \mathrm{a}$ & $35,870 \mathrm{~b}$ & $6.1 \mathrm{a}$ & $2,200 \mathrm{~b}$ & $51,620 \mathrm{c}$ & $5.0 \mathrm{a}$ & $2,560 \mathrm{a}$ \\
\hline Average & 23,038 & 8.9 & 2,050 & 39,815 & 6.2 & 2,468 & 54,810 & 5.0 & 2,702 \\
\hline
\end{tabular}

${ }^{1}$ Values followed by the same letter do not differ significantly at the $5 \%$ level (Duncan's multiple range test). 
difference in yields among the other forages. There were no significant differences among the forages in protein content. However, Sordan 70 produced more crude protein, $2,980 \mathrm{~kg} / \mathrm{ha} / \mathrm{yr}$, than did the other forages.

With a 60-day harvest interval, Sordan 70 produced significantly higher dry matter yields than did Space Maker or Graze and Bale but did not significantly outyield Grazer A. Graze and Bale produced the lowest yields. There were no significant differences in protein content or protein yields among the forages at this harvest interval. Protein content of the forage was generally low.

These data show the tremendously high yields of forage that can be produced by these sorghum-sudan grass crosses when intensively managed under irrigation on the semi-arid south coast of Puerto Rico. With

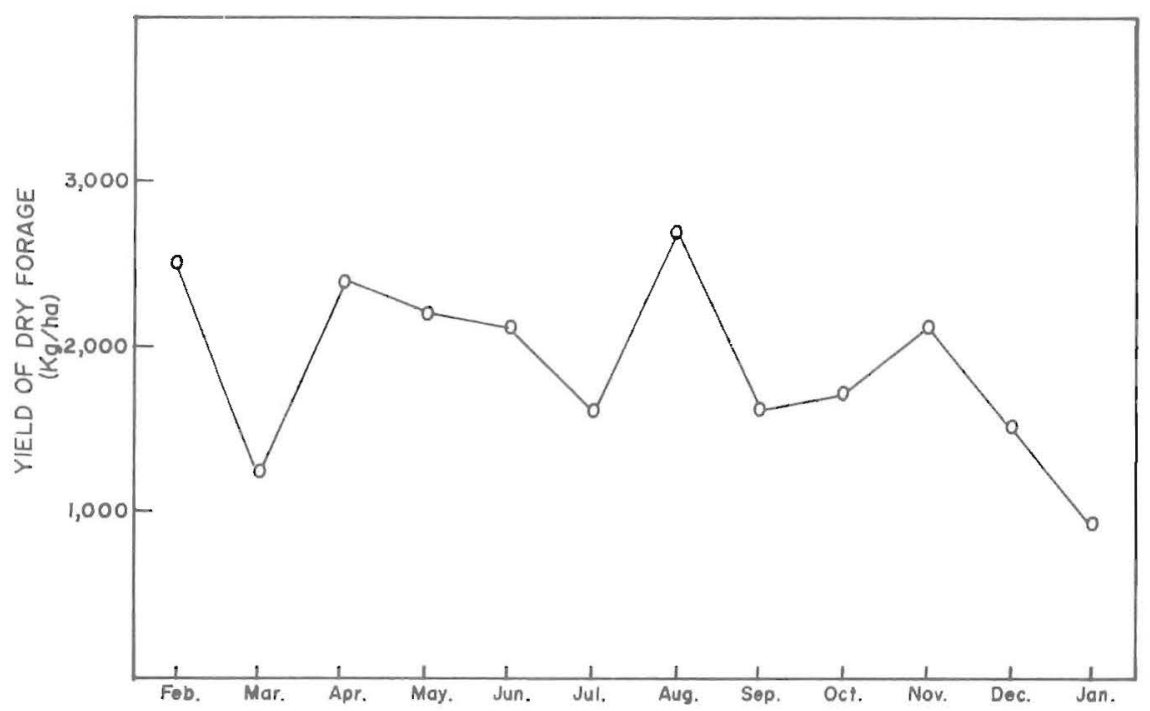

FIG. 1.-Average monthly yields of forage produced by four sorghum-sudan grass forages harvested every 30 days over a 1-year period under irrigation at Santa Isabel, Puerto Rico.

a 60 day harvest interval, these forages produced an average of $54,810 \mathrm{~kg}$ of dry forage/ha/yr, which compares to about $58,000 \mathrm{~kg} / \mathrm{ha} / \mathrm{yr}$ produced by similarly managed Napier grass in this same area in the experiment carried out by Little, Vicente-Chandler and Abruña. ${ }^{5}$

Figure 1 shows average monthly production of forage by the four sorghum-sudan grass forages when harvested every 30 days. Rather uniform, there were high yields during most of the year except during the second month, due to an attack of Army worms and during the last 2 months when the stand started to decline. 
Forage produced by such sorghum-sudan grass crosses under irrigation can be of great value for feeding livestock during the prolonged dry season occurring on the extensive, semi-arid grasslands adjacent to the irrigated lands. It can also be used to supplement pastures in the humid region when their growth is slowed during the winter months of cooler weather and shorter days.

In addition, the sudan-sorghum forage can be pelletized and mixed with concentrates for supplementary feeding of cattle in other areas of the Island.

The production of such high yields of green chopped forage on irrigated lands can also be very important in feeding cattle during the dry season in vast areas of the wet-dry tropics characterized by alternating very wet and very dry seasons.

\section{RESUMEN}

La productividad de los híbridos de sorgo y yerba Sudan Space Maker, Grazer A, Sordan 70 y Graze and Bale se determino en regadio y bien abonados en la costa sur de Puerto Rico.

Estas forrajeras produjeron $23,038,39,815$ y $54,810 \mathrm{~kg}$ de forraje seco/ha y año cuando se cosecharon cada 30,45 y 60 días, respectivamente. El contenido medio de proteína bruta de estas forrajeras fue de $8.9,6.2$ y $5.0 \%$ cuando se cosecharon cada 30,45 y 60 días, respectivamente.

Cuando se cortaron cada 30 días, la Sordan 70 y la Grazer A fueron las de más alta producción. Cortadas cada 45 días, la Sordan 70 fue la más productiva.

El contenido de proteína en todas las forrajeras fue similar cuando se cortaron a distintos intervalos, excepto que la Sordan 70 tuvo un contenido más bajo que el de las otras cuando se cortaron cada 30 días.

Todas las forrajeras produjeron rendimientos similares de proteína a los distintos intervalos, con excepción de la Sordan 70, que contenía menos proteína cuando se cortaron cada 45 días.

Los altos rendimientos producidos por estas forrajeras indican que puede producirse abundante forraje en los terrenos de la costa sur que se pueden regar, como suplemento alimentario para los pastos de la zona ganadera adyacente durante las prolongadas sequías, y en los meses de invierno para los de la región húmeda cuando el crecimiento de los pastos disminuye. 